\title{
Reversible uraemic encephalopathy
}

\author{
Arunmozhimaran Elavarasi, ${ }^{\ominus}$ Vinay Goyal
}

Neurology, All India Institute of Medical Sciences, New Delhi, India

\section{Correspondence to} Professor Vinay Goyal, drvinaygoyal@gmail.com

Accepted 6 April 2019

\section{DESCRIPTION}

Bilateral symmetric white matter changes are usually associated with toxic, metabolic or hereditary leucoencephalopathies. ${ }^{1-3}$ We report an interesting case of uraemic encephalopathy who presented with diffusion restricting symmetric lesions which resolved after renal replacement therapy.

A 19-year-old young obese man presented with fatigue of few days and two episodes of generalised seizures 8 hours apart. There were no other systemic complaints. His medical history was unremarkable. He did not have history of alcohol misuse or illicit drug usage. There was no family medical history of seizures or any neurological problems. There were no focal neurological deficits. His systemic examination was unrevealing. His blood pressure was $180 / 100 \mathrm{~mm} \mathrm{Hg}$. All peripheral pulses were

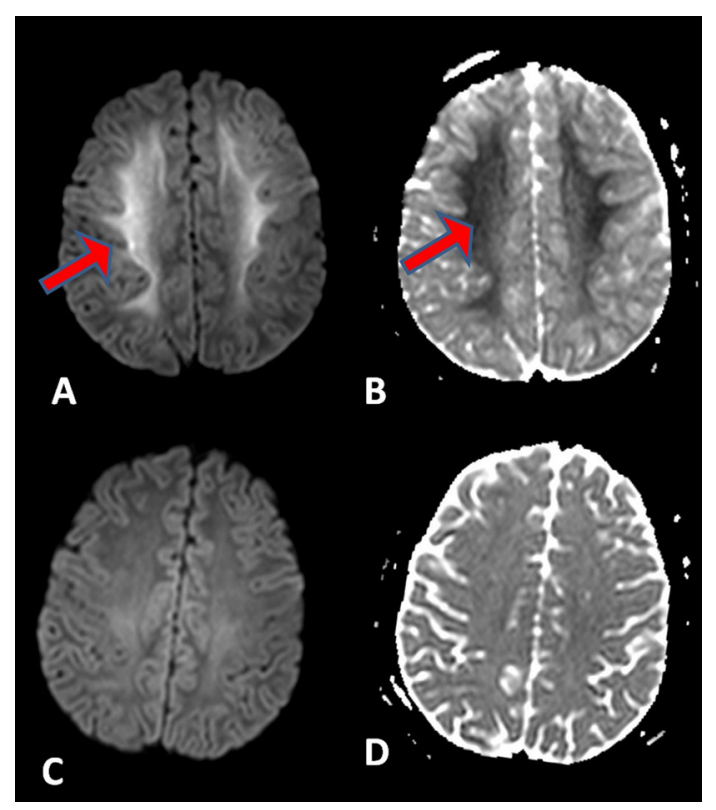

Figure 1 (A) Diffusion-weighted MRI showing restricted diffusion (hyperintensity pointed by red arrow) with (B) showing corresponding hypointensity on apparent diffusion coefficient map. (C) and (D) show the reversal of the changes in $(A)$ and $(B)$, respectively. felt equally with no radio-femoral delay. Imaging was done to look for the aetiology of seizures as well as to look at the pituitary gland as the patient was obese. Simultaneously, blood samples were sent for haematological and biochemical profiles. MRI of the brain (figure 1A, B) revealed bilaterally symmetric diffusion restricting lesions in the centrum semiovale and corona radiata. His creatinine was $22 \mathrm{mg} / \mathrm{dL}$ and he was found to be anaemic. He was initiated on renal replacement therapy. $\mathrm{He}$ had no further seizures. MRI was repeated which showed complete resolution of the diffusion restriction (figure 1C, D).

\section{Learning points}

- Symmetric diffusion restricting lesions are mostly due to acute metabolic derangements, such as renal dysfunction, liver dysfunction, hyperglycaemia or due to chemotherapeutic or illicit drug usage.

- Prompt evaluation and treatment can lead to complete reversal of the clinical symptoms as well as imaging findings.

Contributors $A E$ and VG were involved in diagnosis, management and in writing the manuscript.

Funding The authors have not declared a specific grant for this research from any funding agency in the public, commercial or not-for-profit sectors.

Competing interests None declared.

Patient consent for publication Obtained.

Provenance and peer review Not commissioned; externally peer reviewed.

\section{REFERENCES}

1 Kumar Y, Drumsta D, Mangla M, et al. Toxins in Brain! Magnetic Resonance (MR) imaging of toxic leukoencephalopathy - a pictorial essay. Pol J Radiol 2017;82:311-9.

2 Sivasubramanian S, Moorthy S, Sreekumar K, et al. Diffusionweighted magnetic resonance imaging in acute reversible toxic leukoencephalopathy: A report of two cases. Indian J Radiol Imaging 2010;20:192-4.

3 McKinney AM, Kieffer SA, Paylor RT, et al. Acute toxic leukoencephalopathy: potential for reversibility clinically and on MRI with diffusion-weighted and FLAIR imaging. AJR Am J Roentgenol 2009; 193:192-206. 
Images in...

Copyright 2019 BMJ Publishing Group. All rights reserved. For permission to reuse any of this content visit https://www.bmj.com/company/products-services/rights-and-licensing/permissions/

BMJ Case Report Fellows may re-use this article for personal use and teaching without any further permission.

Become a Fellow of BMJ Case Reports today and you can:

- Submit as many cases as you like

- Enjoy fast sympathetic peer review and rapid publication of accepted articles

Access all the published articles

- Re-use any of the published material for personal use and teaching without further permission

For information on Institutional Fellowships contact consortiasales@bmjgroup.com

Visit casereports.bmj.com for more articles like this and to become a Fellow 